\title{
Teflon strip pneumostasis for excision of giant emphysematous bullae
}

\author{
J M PARMAR, W G HUBBARD, H R MATTHEWS
}

From the Department of Thoracic Surgery, East Birmingham Hospital, Birmingham

ABSTRACT Excision of giant emphysematous bullae commonly results in a persistent air leak that requires prolonged intercostal drainage and delays recovery. To minimise this we have used Teflon (polytetrafluoroethylene) strips to buttress the suture line and secure pneumostasis. During 1976-84 $\vec{\perp}$ eight bullae were excised in seven patients. One patient had bilateral staged thoracotomies. All chest $ᄋ$ drains were removed within eight days (mean 4.5 days) and no patient developed pulmonary $\rightarrow$ complications. At long term follow up (1-9 years, mean 5.5 years) no complications attributable to the Teflon felt have been identified.

Patients with giant emphysematous bullae may require surgical treatment to improve dyspnoea by permitting re-expansion of functional lung or for complications such as pneumothorax, haemoptysis, or infection. Surgical procedures on the emphysematous lung parenchyma pose problems of pneumostasis as the tissues are weak and healing occurs only slowly. Operation is therefore frequently followed by prolonged air leakage with its complications of pneumothorax, atelectasis, and infection. The use of Teflon (polytetrafluoroethylene) buttresses to reinforce suture lines is well established in cardiovascular surgery, so we have applied this technique to resection of giant emphysematous bullae to provide prompt re-expansion of lung and more rapid removal of chest drains. This report describes the operative technique and the results of its use in seven patients.

\section{Patients}

From 1976 to 1984 seven patients required excision of giant emphysematous bullae. The clinical features and indications for surgery are given in table 1 . All patients were male. Two patients (1 and 7) had preoperative air leaks and five had increasing dyspnoea.

The first patient presented with an acute onset of dyspnoea, fever, and pleuritic chest pain. Chest radiographs (fig 1) were wrongly interpreted at another hospital as showing a spontaneous hydropneumothorax, and an intercostal drain was inserted.

Address for reprint requests: Mr H R Matthews, Department of Thoracic Surgery, East Birmingham Hospital, Birmingham B9 5ST.
Within a few days the patient was moribund and required emergency surgery for a persistent major air leak from the bulla, which was by then infected. Four patients $(2,4,5$, and 6$)$ had a history of chronic bronchitis and wheeze with increasing dyspnoea necessitating surgery. Patient 6 had bilateral bullae occupying $80 \%$ of the right hemithorax and $70 \%$ of the left hemithorax. Staged thoracotomies were performed to avoid simultaneous bilateral chest com- $\overrightarrow{\overrightarrow{0}}$ plications. Patient 3 required a left thoracotomy for 3 repair of a hiatus hernia, and because of increasing dyspnoea had simultaneous resection of an ipsilateral bulla. In patient 7 surgery was required for a continuing air leak from a spontaneous pneumothorax.

\section{Technique}

The operation is performed under general anaesthesia $\stackrel{\delta}{\delta}$ with a double lumen endotracheal tube to permit col-

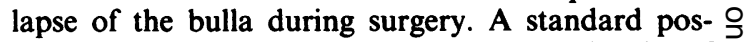
terolateral thoracotomy through the upper border of $D$ the sixth rib is used. The bulla and the remainder of the lung are examined with the lung inflated to define $N$ the extent of the disease (fig 2). The lung is then deflated and a line of resection selected (fig 3 ). If nec- $N$ essary, the bulla can be opened and any major bron- $N$ chial fistulae secured with simple sutures. Two strips of Teflon felt about $1 \mathrm{~cm}$ wide are applied on either $O$ side of the line of resection and a continuous horizon- $\frac{\overparen{D}}{\mathscr{}}$ tal mattress suture of $2 / 0$ silk is passed through all $\stackrel{?}{+}$ four layers (that is, both pieces of felt and both walls 0 of the bulla-fig 4). The tissue of the bulla is then excised (fig 5) and the cut surface oversewn with a $\stackrel{\mathbb{\rho}}{\odot}$ continuous over and over $2 / 0$ silk suture, all four lay- $\mathbb{\mathbb { Q }}$ ers again being incorporated. The lung is then re- 
Table 1 Details of the seven men with giant bullae having Teflon strip pneumostasis

\begin{tabular}{|c|c|c|c|c|c|c|}
\hline $\begin{array}{l}\text { Patient } \\
\text { No }\end{array}$ & $\begin{array}{l}\text { Age } \\
(y)\end{array}$ & $\begin{array}{l}\text { Dyspnoea } \\
\text { grade }^{1 *}\end{array}$ & $\begin{array}{l}\text { Duration of } \\
\text { symptoms }(y)\end{array}$ & $\begin{array}{l}F E V_{1} / F V C \\
(l)\end{array}$ & $\begin{array}{l}\text { Bulla } \\
\text { size } \dagger\end{array}$ & Indication for operation \\
\hline 1 & 55 & $\begin{array}{l}\text { Not } \\
\text { assessed }\end{array}$ & $\begin{array}{c}\text { Emergency } \\
\text { operation }\end{array}$ & $\begin{array}{l}\text { Not } \\
\text { assessed }\end{array}$ & 2 & $\begin{array}{l}\text { Acute infection and bronchopleural fistula } \\
\text { after intubation of bulla }\end{array}$ \\
\hline 2 & $\begin{array}{l}55 \\
62\end{array}$ & $\begin{array}{l}3 \\
3\end{array}$ & $\begin{array}{l}12 \\
12\end{array}$ & $\begin{array}{l}1 \cdot 9 / 3 \cdot 8 \\
2 \cdot 3 / 4 \cdot 4\end{array}$ & $\begin{array}{l}1 \\
2\end{array}$ & $\begin{array}{l}\text { Bronchitic; increasing dyspnoea } \\
\text { Hiatal hernia repair; increasing dyspnoea } \\
\text { with ipsilateral bulla }\end{array}$ \\
\hline 4 & 55 & 5 & 12 & $0 \cdot 8 / 1 \cdot 75$ & 2 & $\begin{array}{l}\text { Minor haemoptysis, increasing dyspnoea; } \\
\text { bronchitis }\end{array}$ \\
\hline 5 & 59 & 4 & 4 & $1 \cdot 2 / 3 \cdot 4$ & 1 & $\begin{array}{l}\text { Previous right spontaneous pneumothorax } \\
\text { followed by increasing dyspnoea }\end{array}$ \\
\hline $\begin{array}{l}6 \\
7\end{array}$ & $\begin{array}{l}45 \\
50\end{array}$ & $\begin{array}{l}5 \\
2\end{array}$ & $\begin{array}{l}10 \\
2 \cdot 5\end{array}$ & $\begin{array}{l}1 \cdot 2 / 2 \cdot 7 \\
\text { Not assessed }\end{array}$ & $\begin{array}{l}3(\mathrm{R}) 2(\mathrm{~L}) \\
2\end{array}$ & $\begin{array}{l}\text { Increasing dyspnoea } \\
\text { Continuing air leak after spontaneous } \\
\text { pneumothorax }\end{array}$ \\
\hline
\end{tabular}

*1-normal; 2-breathless on hills; 3-unable to walk at normal speed on level surface; 4 -limited to 100 yards (91 m) on level surface; 5 -breathless while washing or at rest.

$+1-$ less than $50 \%$ of one hemithorax; $2-50-100 \%$ of one hemithorax; $3-$ greater than one hemithorax.

expanded and tested for pneumostasis. If additional bullae are present they may be ligated or resected as appropriate. Pleurectomy is included if the patient has had a spontaneous pneumothorax. The chest is closed in layers with one underwater seal drain, to which suction is not routinely applied.

\section{Results}

Short and long term results are summarised in table 2 . All drains were removed within 8 days and after a mean interval of 4.5 days and no patient developed a pneumothorax or atelectasis. Postoperative complications occurred in two patients. Patient 1 , who had an infected bulla before operation, developed a superficial wound infection and patient 3 developed a left deep vein thrombosis, which was treated by anticoagulation. All patients have been followed up for periods ranging from one to nine years (mean 5.5 years), and no complications attributable to the use of Teflon felt have been identified. Patient 1 had several minor episodes of haemoptysis between three and four years after operation, but no cause for these was found despite thorough investigation, including fibreoptic bronchoscopy. In addition, there has been no radiographic evidence of inflammation or reaction related to the Teflon felt. Dyspnoea improved in all patients by at least one grade, but one patient subsequently developed progression of chronic obstructive airways disease and congestive cardiac failure.
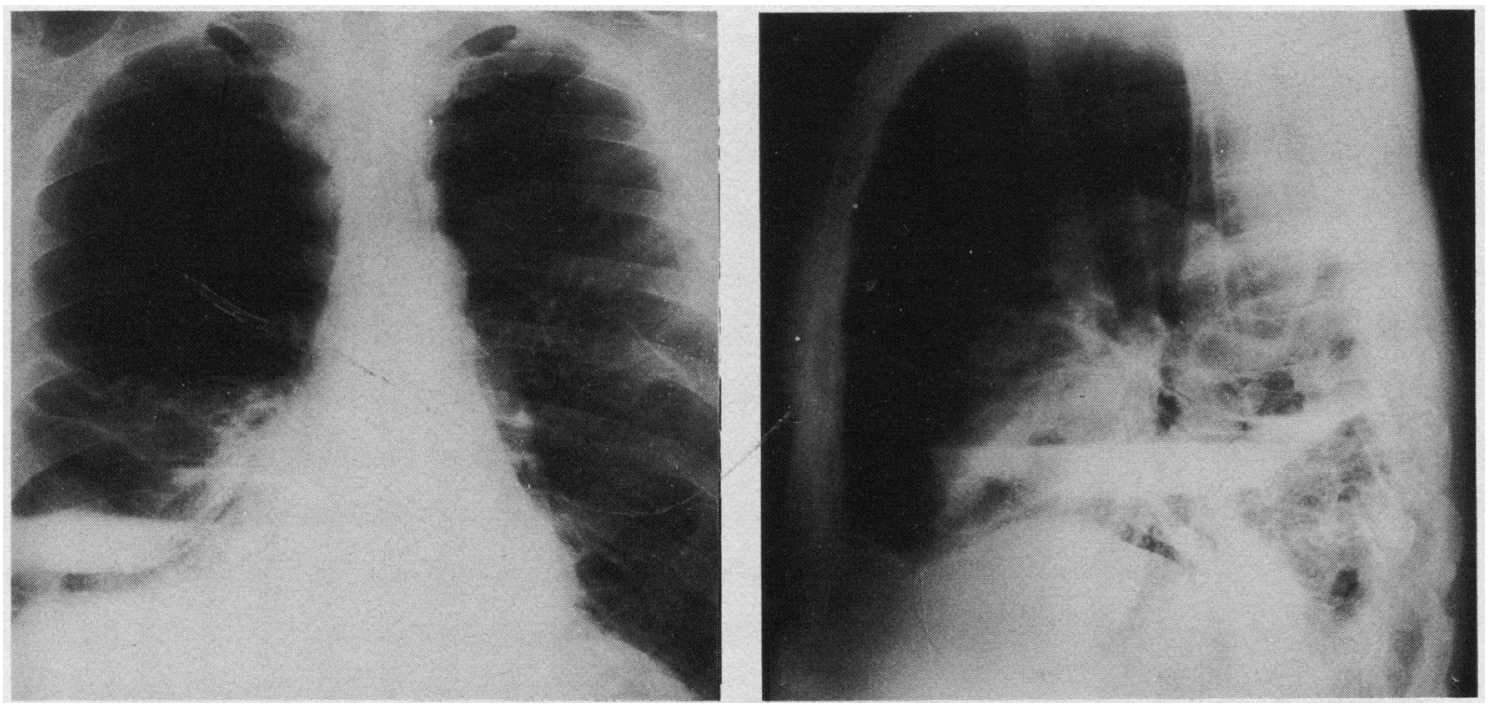

Fig 1 Chest radiographs of patient 1, which were incorrectly interpreted as showing a spontaneous hydropneumothorax. 


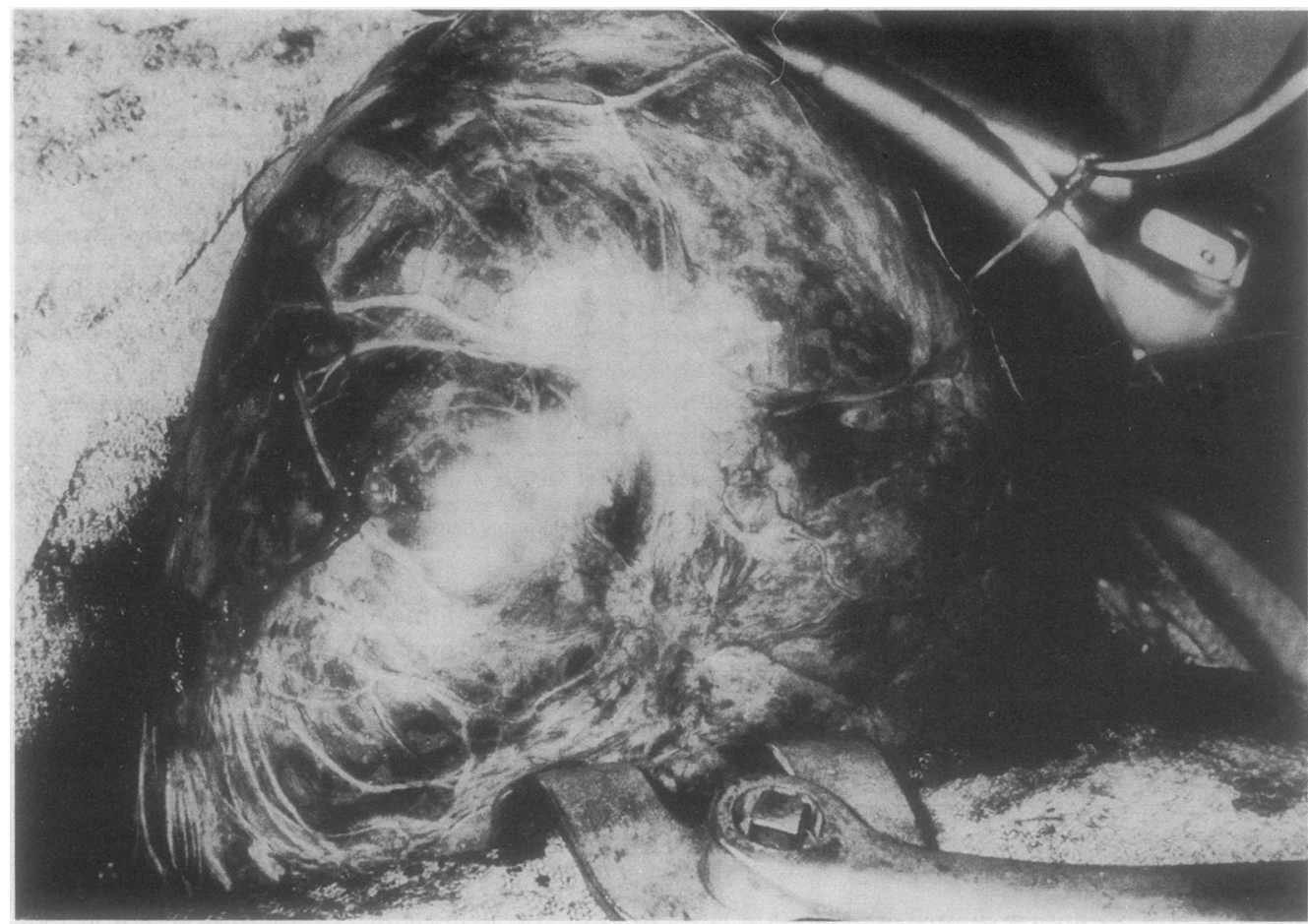

Fig 2 Appearance of bulla at thoracotomy with the lung inflated and showing the extent of the disease.

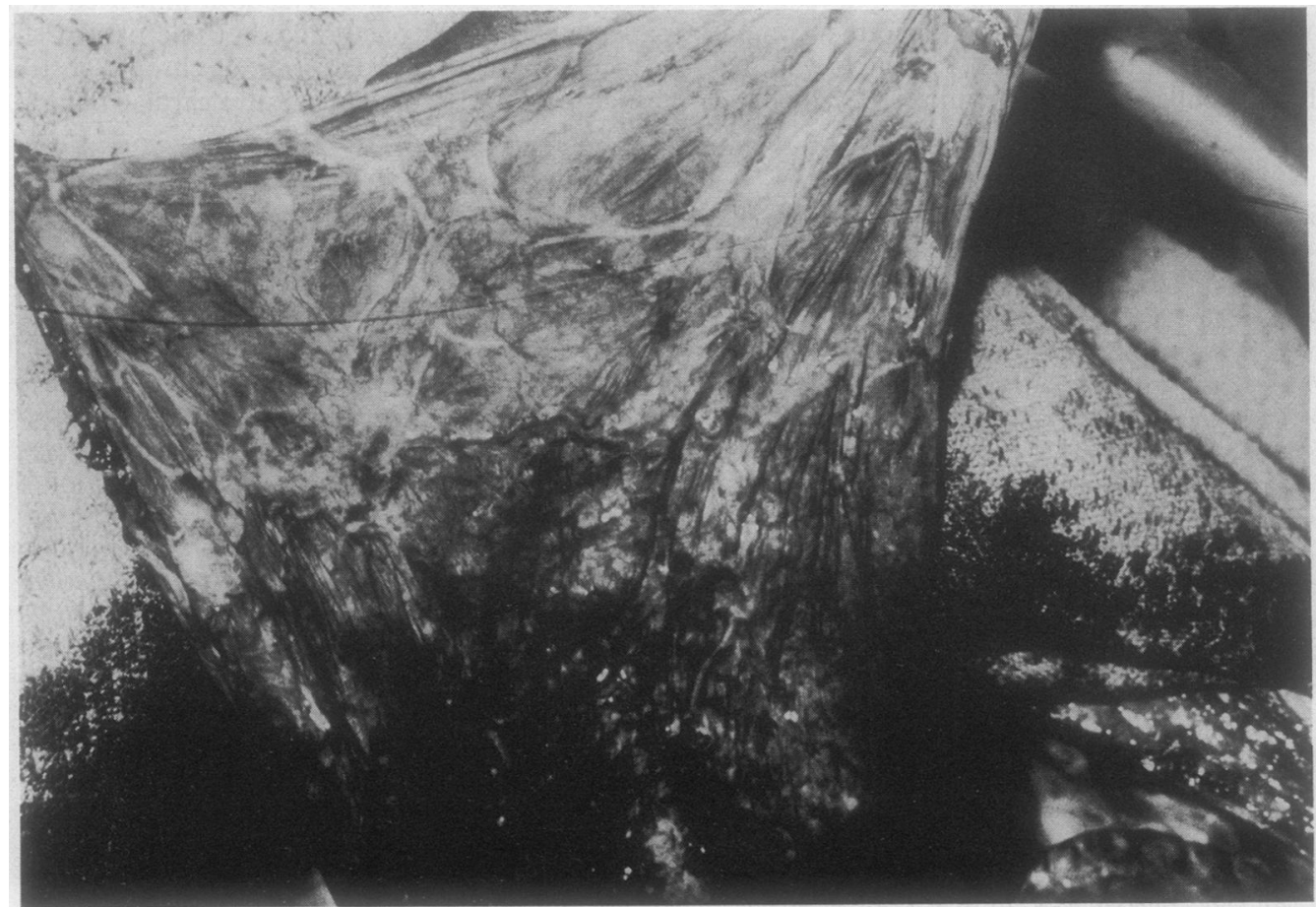

Fig 3 Patient on one lung ventilation showing the deflated lung and bulla. The line of resection can now be determined. 


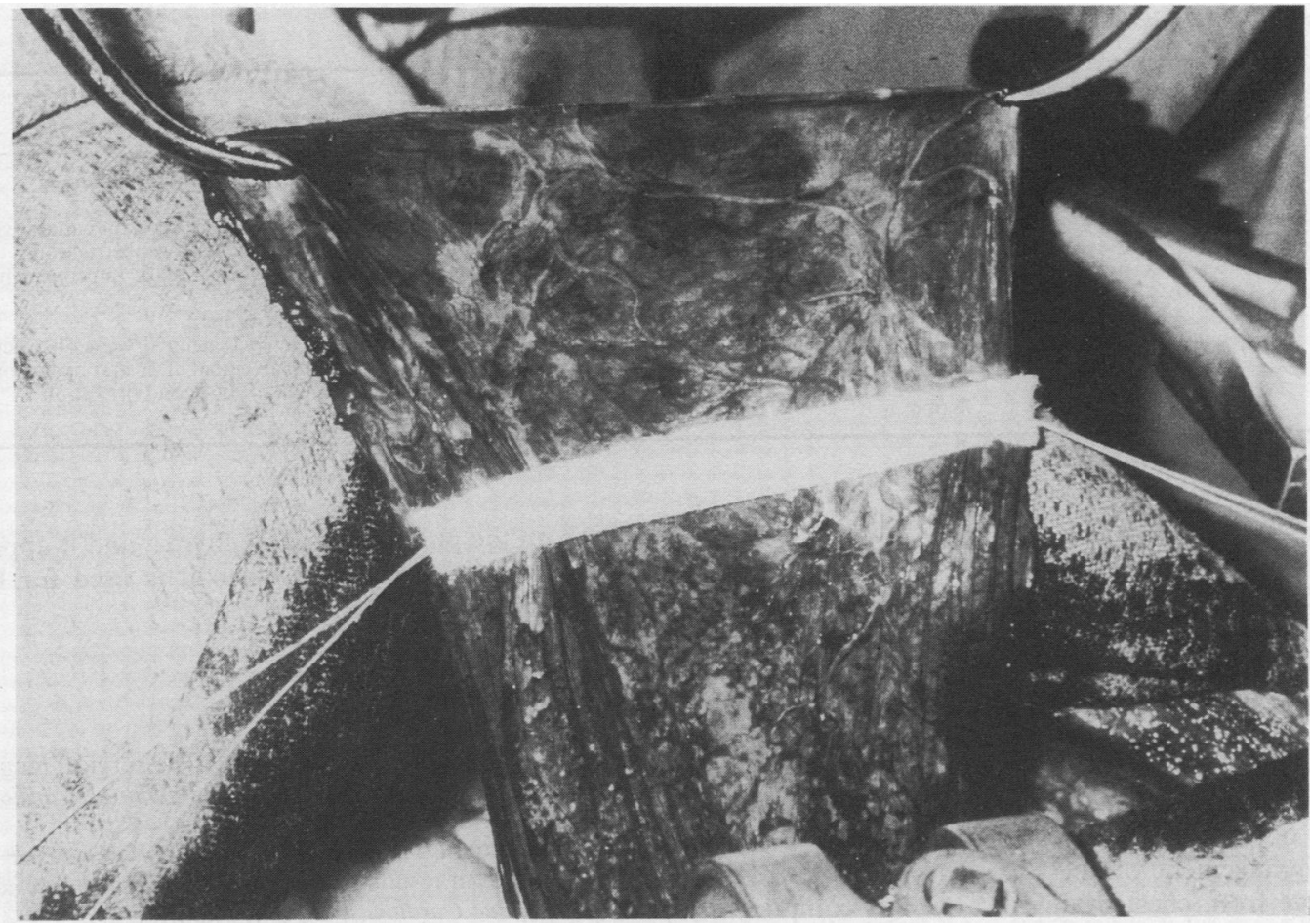

Fig 4 Teflon strips in position across the base of the bulla before suturing with a continuous horizontal mattress silk suture.

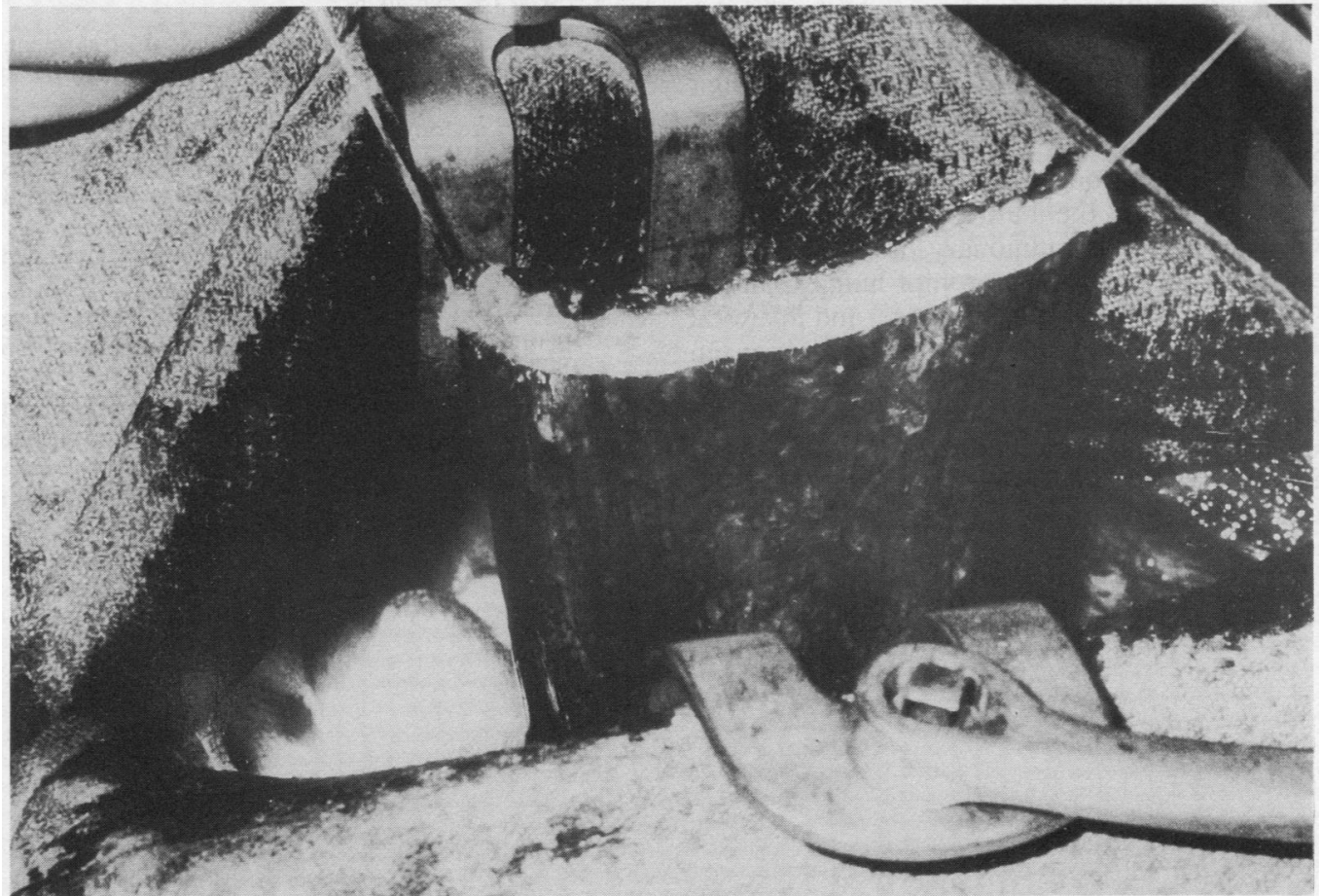

Fig 5 The redundant tissue of the bulla has been excised. The lung can be reinflated and tested for pneumostasis. 
Table 2 Details of the operations

\begin{tabular}{|c|c|c|c|c|c|}
\hline $\begin{array}{l}\text { Patient } \\
\text { No }\end{array}$ & $\begin{array}{l}\text { Drain time } \\
\text { (days) }\end{array}$ & $\begin{array}{l}\text { Hospital } \\
\text { stay (days) }\end{array}$ & $\begin{array}{l}\text { Complications } \\
\text { in hospital }\end{array}$ & $\begin{array}{l}\text { Follow up } \\
\text { (y) }\end{array}$ & Long term results \\
\hline 1 & 5 & 21 & $\begin{array}{l}\text { Purulent sputum } \\
\text { Infected wound }\end{array}$ & $9 \cdot 3$ & $\begin{array}{l}\text { Minor haemoptysis 3-4 years after operation; sustained } \\
\text { improvement in dyspnoea }\end{array}$ \\
\hline 2 & 3 & 13 & None & $8 \cdot 3$ & $\begin{array}{l}\text { Temporary improvement in symptoms; long term congestive } \\
\text { cardiac failure and progression of airways obstruction }\end{array}$ \\
\hline 3 & 1 & 19 & $\begin{array}{l}\text { Deep vein } \\
\text { thrombosis }\end{array}$ & 8 & No long term sequelae; sustained symptomatic improvement \\
\hline 4 & 5 & 15 & None & 5 & Sustained and considerable improvement \\
\hline 5 & & & None & $4 \cdot 5$ & Initial improvement followed by increasing airways obstruction \\
\hline 6 & $\begin{array}{l}7(\mathbf{R}) \\
3(\mathbf{L}) *\end{array}$ & $\begin{array}{r}12(\mathrm{R}) \\
8(\mathrm{~L}) *\end{array}$ & $\begin{array}{l}\text { None } \\
\text { None }\end{array}$ & 3 & $\begin{array}{l}\text { Considerable symptomatic improvement after first operation; } \\
\text { slight additional improvement after second operation }\end{array}$ \\
\hline 7 & 4 & 8 & None & 1 & Dyspnoea improved \\
\hline
\end{tabular}

*Staged thoracotomies (see text).

\section{Discussion}

The criteria for surgical selection of patients with bullous disease remain incompletely defined, though reports generally suggest that patients with bullae occupying more than one third of one hemithorax who have symptoms would expect significant improvement. $^{23}$ This, however, may not be maintained because of progression of the underlying airways obstruction. ${ }^{4}$ One of the greatest problems in the management of these patients is prolonged air leakage from chest drains. ${ }^{256}$ Serious complication rates of $25-50 \%$ have been attributed to failure to obtain prompt re-expansion of the lung. ${ }^{7}$

Techniques used to deal with giant bullae include lung resection, decompression by intracavitary suction, ${ }^{8}$ and excision by simple suturing or stapling. ${ }^{9}$ The problem with these forms of excision is that staples and sutures may cut out of the diseased lung tissue, leading to prolonged air leaks. The merit of the Teflon strip lies in the buttressing it provides to prevent tearing of the pulmonary tissue. Using this technique, we have obtained prompt lung expansion without prolonged chest tube drainage, and in a total of 39 patient years of follow up there have been no documented infective or foreign body complications related to the Teflon felt.

Thus in our experience the use of Teflon felt has provided secure and safe lung closure for the excision of giant bulla. It may also be of value in other oper- ations on the pulmonary parenchyma, and it appears to be as well tolerated as when it is used for haemostasis in the circulation.

\section{References}

1 Gunstensen J, McCormack RJM. The surgical manage- $\vec{\oplus}$ ment of bullous emphysema. $J$ Thorac Cardiovasc Surg 1973;65:920-5.

2 FitzGerald MX, Keelan PJ, Cugell DW, Gaensler EA. Long term results of surgery for bullous emphysema. $J$ Thorac Cardiovasc Surg 1974;68:566-86.

3 Woo-Ming M, Capel LH, Belcher JR. The results of surgical treatment of large air cysts of the lung. $B r J D i s \stackrel{\mathbb{Q}}{\mathscr{Q}}$ Chest 1963;57:79-85.

4 Pearson MG, Ogilvie C. Surgical treatment of emphysematous bullae: late outcome. Thorax 1983; 38:134-7.

5 Ray JF, Lawton BR, Smullen WA, Myers WO, Sautter RD. Effective surgical palliation of giant compressive bullous emphysema (vanishing lung syndrome): long term follow-up. Am Surg 1976;42:181-5.

6 Billig DM, Boushy SM, Kohen R. Surgical treatment of bullous emphysema. Arch Surg 1968;97:744-9.

7 Delarue NC, Woolf CR, Sanders DE, et al. Surgical treatment for pulmonary emphysema. Can J Surg 1977;20:222-31.

8 MacArthur AM, Fountain SW. Intracavitary suction and drainage in the treatment of emphysematous bullae. Thorax 1977;32:668-72.

9 Allen TH. Technic for resection of localised bullous dis- N ease of the lung. Am Surg 1971;37:671-6. 